\title{
Role of Organizational Ethics in Sustainable Development: A Conceptual Framework
}

\section{Phathara-on Wesarat ${ }^{\mathrm{a}^{*}}$, Mohmad Yazam Sharif ${ }^{\mathrm{b}}$, Abdul Halim Abdul Majid ${ }^{\mathrm{b}}$}

\author{
${ }^{a}$ Faculty of Humanities and Social Sciences, Prince of Songkla \\ University (Pattani Campus), Pattani 940oo, Thailand \\ ${ }^{b}$ College of Business, Universiti Utara Malaysia, UUM Sintok \\ o6o1o, Kedah Darul Aman, Malaysia
}

Received: November 30, 2015 / Accepted: January 19, 2017

\begin{abstract}
The focus of many organizations worldwide has been changing from greater productivity and profit maximization to sustainable development. Those organizations that focus on profit-only often make shortterm decisions without concern for long-run sustainable benefits. The concept of organizational ethics has been widely discussed as it may provide the means to long-term business success. This paper considers the basis of organizational ethics as an integration of ethical climate and culture in organizations that has an important impact on ethical decision-making and outcomes, which in turn could lead to sustainable development. The challenge of businesses is to remain ethical to stakeholders under conditions of uncertainty. They are expected to serve sustainable development not only for the benefits of
\end{abstract} themselves, but also the interests of others in society.

Keywords: organizational ethics; ethical climate; ethical culture; sustainable development.

\section{Abbreviations:}

\begin{tabular}{|lll|}
\hline CC & $:$ & Corporate citizenship \\
CS & $:$ & Corporate sustainability \\
CSR & $:$ & Corporate social responsibility \\
CSD & $:$ & Corporate sustainable development \\
SD & $:$ & Sustainable development \\
\hline
\end{tabular}

\footnotetext{
*orresponding Author

Tel.: +6673331304 ; Fax.: +6673312232 ; E-mail: phatharaon.w@psu.ac.th
}

\section{Introduction}

In line with rapid technological and economic changes, there is increasingly intense global competition among firms. Many organizations put a lot of effort towards gaining competitive advantages over their competitors [1]. In order to achieve business success, they adopt business strategies (e.g. maintaining customer relationships [2], manufacturing differentiated products, and using cost leadership strategies [3]). Normally, the main goal of businesses is to maximize profit for themselves [4]. Thus, various managerial tools have been used to improve organizational profitability [5]. However, companies' focus on short-term profit maximization may lead to corporate debacles such as Enron and WorldCom. Such financial scandals were caused by unethical decisions and irresponsible behavior [6]. These scandals damaged the credibility and trust of accounting firms more generally [7]. As people have a perceived negative image of such firms, it is not easy to resolve the credibility crisis. It will be better for all businesses if they proactively pay attention to preventing such a credibility crisis. They may need appropriate tools (e.g. the ethical standards of firms) to be used to ensure long-term credibility.

It is quite difficult for businesses to remain successful over a long period of time (i.e. sustainable success) [8]. Those organizations who have adopted short-term cost savings strategies might downplay their performance with regards to environmental and social responsibility. As a result, their long-term business growth may decline. A global trend towards business operations is to place more focus on sustainability - involving not only environmental issues, but also social and ethical issues [9]. They must be aware of the sustainability of their businesses, communities, and regions. On one hand, businesses can affect the environments in which they operate. On the other hand, businesses are affected by the surrounding systems [10]. From an organizational ethics perspective, businesses are expected to be responsible for serving and protecting their stakeholders as well as the community as a whole. From this perspective, businesses can play a significant role to support the mission of sustainable development of the country. The business sector is the key actor whose business strategies should be made to respond to the current phenomena of unsustainable development (e.g. the effects of increased greenhouse gas emissions). Hence, the full participation of businesses in reducing their emissions is required.

The term "sustainable development" refers to "development that meets the needs of the present without compromising the ability of future generations to meet their own needs" [11]. At an organizational level, corporate ethical practices are supposed to respond to the needs of both present and future generations. Therefore, companies should operate based on principles of ethics that provide practical knowledge or guidelines for doing the right things 
[12]. Companies may have multiple stakeholders (e.g. shareholders, employees, suppliers, customers, and others who can be affected by the firm's activities) whose interests need to be protected to achieve sustainable success [13]. In doing so, many companies have established sustainable development programs (e.g. AccountAbility 1000 (AA 100o), Social Accountability 80oo (SA 80oo), and Corporate Social Responsibility (CSR)) in response to the environmental and social impacts of corporations [14]. Previous studies - e.g. Wallis [15], Grbac and Lončarić [16] - show the link between ethics and social responsibility in the business sector. CSR has been viewed as a means for sustainable development [17]. The effectiveness of implementing sustainable development programs may depend on the degree to which organizations emphasize organizational ethics. Since companies need to find an appropriate way to support and maintain sustainable development, ethics in the workplace seems to be supportive of corporate sustainable development (CSD) [18]. This is because ethics focuses on the long-term development of human society [18]. The establishment of organizational ethics that is composed of an ethical climate and culture in organizations, encourages good sustainable development practices [19].

Ethical climate and ethical culture in an organization have been recognized as important to business outcomes (such as organizational commitment, job satisfaction, and ethical decision-making) [20]. A study by ShapiraLishchinsky [21] states that there is a relationship between individuals' perceptions of organizational ethics and their job withdrawal behaviors (e.g. absence and intent to leave jobs). They expect organizations to provide ethical environments in exchange for their loyalty (e.g. coming on time and remaining in their jobs) [21]. The appearance of ethics in organizational settings has a positive influence on individuals' behaviors. Normally, corporate ethics attracts people to participate in a company's activities - for example, not only do investors choose to deal with socially responsible firms but employees also choose to work for them [22].

Differentiating the meaning of the two terms "ethical climate" and "ethical culture" is important in order to have a clear understanding of the concepts discussed in this paper. Ethical climate refers to employees' perception of how ethical their organizations are [23]. In the workplace, managers can influence the organizational ethical climate because employees observe supervisors' behaviors and then they may copy these behaviors [24]. Ethical culture represents the formal and informal control systems which have more influence on employees' ethical behaviors than ethical climate [25]. Ethical climate reflects a more symbolic understanding of an organization's ethics while ethical culture plays a more operational role in promoting ethical behaviors [25]. Without organizational ethics, employees' unethical behaviors rise in the workplace [26].

In this paper, organizational ethics are considered as extremely important to achieving sustainable development of firms [27]. Organizational ethics affects ethical decisionmaking and outcomes [28]. Thus, it can play a role in influencing how well the organizations operate to meet the needs and interests of their stakeholders without harming others in society. Organizations should learn how to effectively promote ethical standards among their members. Ethics should be integrated into the key components of business strategies. The impacts of business strategies on sustainable development are through the ability to solve problems (e.g., environmental problem, social injustice, and economic problem) under the current conditions of unsustainable development. Business strategies are supposed to rely on ethical economics (using resources in sustainable way), social justice (producing the greatest benefit for the greatest number of people), and a sustainable environment (creating sustainable environmental management) [29]. This paper therefore starts from the premise that organizational ethics have an impact on the success of sustainable development because it encourages individuals to behave in ethical and sustainable ways. It then presents the concept of sustainable development (at the macro and micro levels) as well as the concept of organizational ethics (encompassing ethical climate and ethical culture).

\section{The Concept of Sustainable Development}

The concept of "development" in social sciences is viewed as a process that aims at improving people's well being. It has four dimensions: socio-economic, cultural, political and psychological [30]. Recently, the new concept of "development" has exphasized the importance of appropriate development in which the development goals are to do the best things for individuals, communities, and environment [31]. Its concerns are not just with corporate profits and the gross domestic product (GDP) of a country [31]. The concept of appropriate development is linked to sustainable development (SD). The term "sustainable development" is a process for meeting the goals of human development while at the same time sustaining natural systems to continue providing natural resources and ecosystem services upon which the economy and society depend [32]. While the modern concept of sustainable development is derived most strongly from the 1987 Brundtland Report [11], it is rooted in earlier ideas about sustainable forest management and twentieth century environmental concerns.

Besides this, the United Nations also developed a model called "The Circles of Sustainability" to help countries understand the meaning of "sustainable development" and "sustainability". This model covers four aspects of life on Earth, namely economics, ecology, politics and culture (see figure 1). It aims to achieve the continued well-being of the economy, ecological, political, and cultural base [10]

While the term "sustainable development" was initially used at the global level, it has been increasingly applied to the corporate context [33]. This paper concerns SD at the organizational level. This is part of the macro level or 
national SD. This is currently referred to as corporate sustainable development (CSD). CSD is the role and responsibility of corporate managers, and was previously known as corporate social responsibility (CSR) or corporate citizenship (CC).

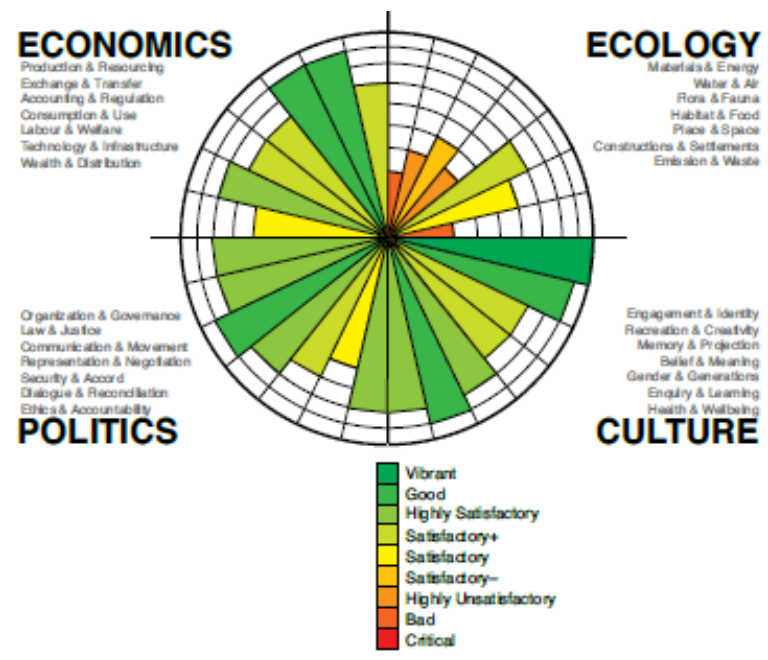

Figure 1 The circles of sustainability

Source: United Nations Global Compact Cities Programme (as cited in Global Cities Research Institute) [34]

Businesses are the elements within an economic system which operate to serve human society [10]. At the organizational level, sustainable development issues have been widely discussed by many scholars e.g. $\mathrm{Wu}, \mathrm{He}$ and Duan [35], Chow and Chen [36], Bai, Sarkis and Dou [37], but the meaning of sustainable development is often perceived differently by different organizations [38]. They have usually committed to sustainable development practices encompassing different dimensions. For example, some organizations have a commitment to green practices (e.g. reducing pollution emissions and energy consumption) [39] while some others have a commitment to their longterm business survival [38]. Even though there is no consistent definition of "sustainable development" used among various firms, their adoption of different dimensions of the term "sustainable development" has still been viewed as helpful to their long-term success [40]. Organizations that are concerned about sustainable development should improve their sustainability performance. They must find possible methods/ways to promote sustainable development in their companies [41].

Although there is a connection between SD and social responsibility, the meaning of these two terms is not exactly the same [41]. Social responsibility reflects the intrinsic nature of business that causes its social responsibility actions, and usually focuses on short-term actions. Businesses often invest in social responsibility (CSR performance) in a trade-off with their financial returns. On the other hand, SD is a broader concept than social responsibility. SD requires long-term actions and covers various topics [41]. SD is frequently used at the macro level (integrating global economic, social, and environmental dimensions).

Additionally, corporate sustainability (CS) is viewed as a concept that orients the existence of a firm [41]. CS needs support from the corporate citizenship role. The term "corporate citizenship" is connected with CSD as it is defined as "working to meet a firm's economic, ethical, legal and discretionary responsibilities to the wider society" [42]. Based on this concept, corporate citizenship can be used to provide better quality services to customers, improve employee motivation, and offer moral value to stakeholders [41]. Proactive corporate citizenship actions have a positive impact on business performance [42]. It can be concluded that both CSR and CC actions of a firm can support sustainable development at the organizational level (micro level), which in turn would benefit sustainable development at the macro level.

The predominant corporate sustainable development framework is composed of an integration of three dimensions: economic, social, and environmental development [36]. Therefore, corporate sustainability can be defined as a long-term organizational change process which aims to enhance the economic, environmental, and social competence of the organization [34]. Those organizations that are able to launch comprehensive CSD can gain and sustain competitive advantage over time. Corporate sustainability performance needs to be strengthened by organizational ethics. This paper highlights organizational ethics as a determinant of an organization's sustainable development performance.

\section{Organizational Ethics}

Ethics is known as a branch of philosophy that is related to principles of good and bad [43]. This paper considers ethics from a business point of view. Principles of ethics provide useful guidelines for organizational practices, because they clarify what is "right". They assist businesses to make moral decisions and take ethical actions [44]. Organizational ethics encompasses basic ethical values (integrity, honesty, fairness, responsibility, etc.) shared by an organization's members [45]. Organizational ethics provides "a framework for ethical discourse across all aspects of the organization and creates a framework through which an institution can recognize the relational nature of its being; its impact, positively and negatively, on others" [46].

Organizational ethics requires the support of an organization's ethical vision and strategy [47]. With this underpinning, companies should have the capacity to carry out ethical strategic plans [47]. They must protect the interests of all related parties. They are not only responsible for meeting the needs of shareholders (e.g. increasing profit for shareholders), but they should also protect the interests of other parties (e.g. not to damage the natural environment, not to harm human rights). Organizations 
that generate a set of principles of ethics might develop a guiding framework for ethical practices, but the effectiveness of ethical practices depends on the capabilities of both employers and employees. They should be able to analyze the ethical aspects of problems, identify alternative ethical solutions to the problems, and choose the most appropriate ethical solution [48]. This indicates the requirement for competent practitioners to implement the ethical strategic plans of the firms.

Companies may integrate the principles of ethics into management process (planning, organizing, staffing, directing, and controlling) to ensure their implementation of ethical strategic plans [49]. Since organizations can implement an ethical strategy through organizational management, many of them enhance ethical performance by using a code of ethics as a practical guideline [50]. The code of ethics is not just about right and wrong, but presents a contractual sense of duty to all employees [51]. They must be motivated to perform their work in accordance with the code of ethics. Organizations that demonstrate organizational ethics are respected by stakeholders [45]. Brooks and Dunn [45] maintain that businesses should demonstrate organizational ethics throughout their organizations and all their business dealings. This paper sheds light on the importance of organizational ethics in sustainable development, while previous studies have shown that the achievement of sustainable development goals is affected by the intention of employees to act ethically. Employees' intention to behave ethically to serve sustainable development goals may depend on the extent to which they perceive their organizational ethics $[52,53]$. A study by Koh and Boo [54] states that the ethical climate and ethical culture are related aspects of organizational ethics. Previous studies have found that organizational ethics increases employees' commitment [54]. Both ethical climate and ethical culture in the organization assist employees to build a strong sense of ethics. According to the development of ethical climate and culture in the organizations, their employees are likely to be aware of the importance of ethical performance. However, organizational ethics implementation is affected by regulations and policies of the state, and relevant international laws. Businesses therefore need supportive regulations to boost their ethical performance [55].

Organizations that are successful in promoting organizational ethics may achieve the sustainable development goals of the firm. This paper developed a framework that is useful for conducting research on the role of organizational ethics in sustainable development (see figure 2). The independent variable in this case is "organizational ethics" (comprising two aspects; ethical climate and ethical culture) while the dependent variable is "sustainable development". The definitions and concepts of the two terms "ethical climate" and "ethical culture" are discussed in this section. The positivist methodology can be used to evaluate the interrelation between organizational ethics and sustainable development because the purpose of a conceptual framework is examine reality, which can be measured and exists apart from the researchers [56].

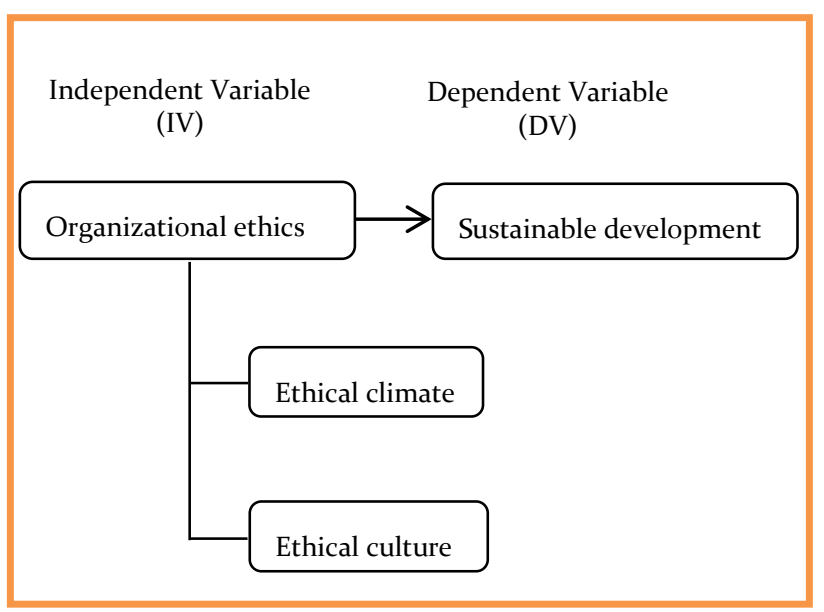

Figure 2 A conceptual framework

Figure 2 shows that there is the possible link between organizational ethics and sustainable development [57]. Sustainable development is hypothesized to be affected by organizational ethics, consisting of two elements, ethical climate and ethical culture.

\subsection{Ethical Climate}

Ethical climate is a type of work climate in an organization [58]. It is defined as the shared set of understandings about what ethical behavior is and how to behave ethically [59]. It influences individuals' perception of how their organization encourages ethical behavior throughout the organization [6o]. It further refers to individuals' shared perceptions of ethical practices and procedures of their organization [61]. Ethical climate is significantly associated with ethical behaviour [58,61]. On one hand, an organization's members who perceive their organizational climate as ethical often show concern for the importance of corporate ethics and social responsibility (e.g. concern for stakeholders affected by their performance) [62]. On the other hand, employees who perceive an unethical organizational climate are likely to minimize the importance of ethics and social responsibility [63]. Kim and Miller [64] suggest that organizations should create an appropriate ethical climate that reinforces ethical behaviors of their employees. In doing so, an ethical climate model may be required to foster their organizational ethical climate.

Martin and Cullen [65] identified five ethical climate types that are caring, independent, law and code, rules, and instrumental (see Figure 3). The first, caring is an ethical climate type that emphasizes concern for others (e.g. concern for well-being of others) [58]. The second, independent climate, reflects the situation in which persons act in accordance with their own personal moral beliefs 
[58]. The third, the law and code climate, is based on the perception that the organization supports decision-making based on external codes such as law and professional codes of conduct [65]. The fourth, rules, dimension of ethical climate is related to accepted rules of conduct determined by the firm [58]. Organizational decisions are guided by local rules or standards such as codes of conduct [65]. The fifth, the instrumental climate, is associated with the egoistic criterion used for decision-making. Organizational decisions are based on its personal interests [58].

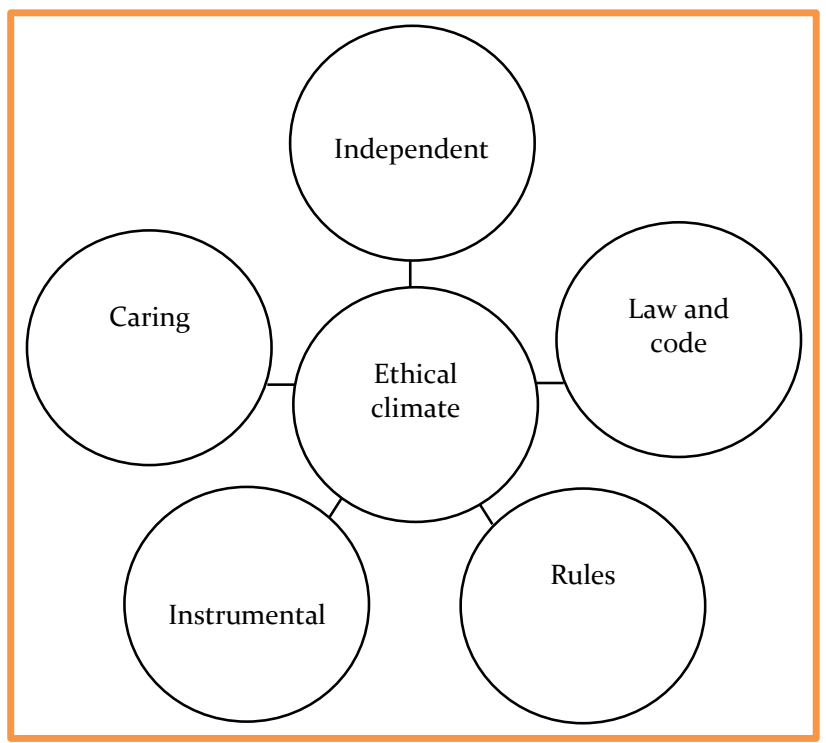

Figure 3 Five ethical climate types

Figure 3 presents five ethical climate types comprising caring, independent, law and code, rules, and instrumental. An adoption of the ethical climate model could encourage ethical decision-making and ethical behaviors at the workplace. Its consequences, therefore, support the mission of sustainable development.

Basically, ethical climate has a positive relationship with job satisfaction. The perceived ethical climate of an organization makes employees feel satisfied with work. Considering the relationship between different types of ethical climate and job satisfaction, a study by Martin and Cullen [65] found that four types of ethical climate - caring, independent, law and code, and rules - influence job satisfaction positively. These four types of ethical climate can be applied to maintaining employees' job satisfaction. Conversely, employees' perceptions of instrumental ethical climate have negative effects on job satisfaction [65]. Additionally, ethical climate can influence organizational commitment [58]. The term "organizational commitment" refers to a force that binds an individual to be involved in organizational activities and to remain in the organization $[66,67]$. Since employees who perceive a positive ethical climate are committed to their organization, they are expected to be committed to their organization's mission of sustainable development as well. This is because committed employees often pay a lot of attention to their organization's work activities (including the organization's sustainable development activities).

\subsection{Ethical Culture}

Ethical culture is considered as one aspect of organizational ethics. Normally, ethical culture encompasses "the experiences, presumptions, and expectations of how the organization is preventing unethical behavior and promoting ethicality" [68]. Ethical culture reflects a set of formal and informal organizational control mechanisms that aim to influence ethical behavior of an organization's members [54]. Ethical culture has been viewed as a determinant of ethical behaviour [69]. It simulates ethical conduct (i.e. positive behavior) [7o]. It can foster individuals to perform ethically and avoid wrongdoing [71]. Ethical culture plays a crucial role in enhancing an organization's ethical performance as well as monitoring sustainable ethical business practices [72].

Previous studies (e.g. Pflugrath, Martinov-Bennie and Chen [73], Whyatt, Wood and Callaghan [74]) determined the importance of sustainable development programs (e.g. the code of ethics). The research findings by Pflugrath, Martinov-Bennie and Chen [73] state that the code of ethics (namely International Standard on Quality Control 1: ISQC1) has a positive impact on the quality of auditors' judgments. These findings confirm that the code of ethics benefits the organization in terms of ethical performance improvement and corporate ethical reputation [74]. The code of ethics not only encourages employees to perform ethically and professionally, but it also shows a signal to the public that a code of ethics exists within a company [74]. Using the code of ethics is helpful for a company to promote its positive image and reputation.

However, the accomplishment of such sustainable development programs as mentioned earlier, requires the support of ethical culture. A study by Park and Blenkinsopp [75] argues that employees' compliance to the code of ethics is increased when it is supported by ethical culture. Some evidence supports that a strong ethical culture in the organization may provide it with financial benefits [76]. Their reputation for ethical culture is associated with a high level of employee and customer loyalty [76]. Hence, it can be said that doing business ethically can improve financial performance. Many companies realize the significance of ethical culture but they need to know how to promote ethical culture in the workplace. The corporate ethical virtues (CEV) model developed by Kaptein [76] is one approach that could be applied to promote the ethical culture of an organization (see Figure 4). 


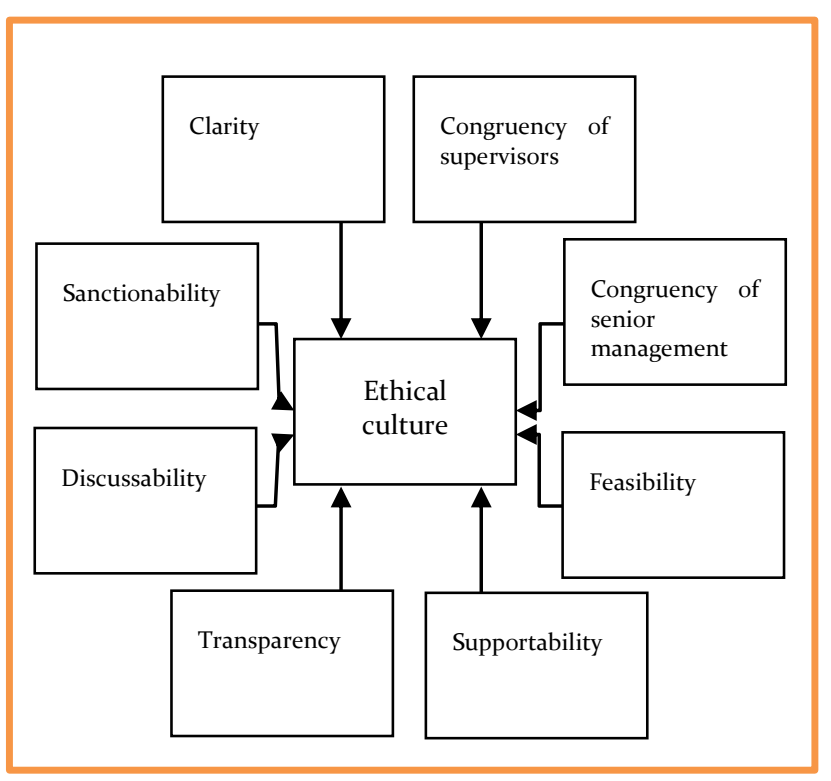

Figure 4 The CEV model

Figure 4 highlights the link between the eight organizational virtues (clarity, congruency of supervisors, congruency of senior management, feasibility, supportability, transparency, discussability, and sanctionability) and ethical culture. The presence of these organizational virtues could be helpful to develop organizational ethical culture. These organizational virtues are discussed as follows.

First, an organization with the clarity of normative expectations regarding ethical conduct assists its employees to distinguish between ethical and unethical conduct [77]. Second, congruency of supervisors and third, congruency of senior management, with these normative expectations, encourage employees to behave ethically. If supervisors and senior management show an example of ethical behavior, employees will be motivated to do the same [68]. Fourth, feasibility refers to the extent to which an organization sets the conditions which enable employees to act in accordance with the normative expectations [77]. Unethical behavior of employees might occur when they lack the conditions or resources (such as time, budgets, information, etc.) provided by an organization to fulfill their responsibilities [77]. Fifth, supportability refers to the extent to which an organization supports its employees to meet normative expectations [77]. The organization should be able to motivate its members to comply with ethical standards. Sixth, transparency or visibility in the organization is important to the encouragement of ethical decision-making and behavior among employees [77]. It is defined as "the degree to which employee conduct and its consequences are perceptible to those who can act upon it" [77]. Seventh, discussability is the opportunities to discuss ethical issues in a company [68]. A high level of discussability helps employees to realize their ethical/unethical behavior in order to make them feel they are ready to improve their conduct [68]. Eighth, sanctionability refers to the extent to which the organization reinforces ethical behavior in the workplace by rewarding ethical behavior and punishing unethical behavior [68]. The organizational virtue of sanctionability reflects that the organization values ethical behavior [68].

The CEV model provides an understanding of the determinants of ethical culture. Organizations with the capability to create ethical virtues can gain success in developing an ethical culture in the workplace [77]. However, the CEV model should be investigated further, particularly in different areas or regions where people hold different cultural values. The CEV model may need to be adapted to a specific area in order to effectively produce an ethical culture in various types of organizations as well as in various countries.

\section{Discussion}

Many studies (e.g. Ciasullo and Troisi [78], Milne, Tregidga and Walton [78], Venkatraman and Nayak [8o]) agree that the idea of corporate sustainable development (CSD) has become important to all businesses since it presents the means to promoting long-term success. Brundtland's definition of sustainable development has been used as a basis for corporate SD [81]. The concept of corporate sustainability is mainly based on three principles: economic integrity, social equity, and environmental integrity [57]. Organizations tend to reach these three principles as they facilitate sustainable development. Moreover, organizations that are able to develop and sustain organizational ethics would logically be better equipped to respond to the needs of present stakeholders without hurting the ability of future generations to meet their own needs. In practice, organizations should set managerial tools to support and reinforce ethical performance so that their members behave in accordance with the organizations' ethical standards. Ethics influences daily behaviors and decision-making in organizations at all levels [82]. Companies should know how to effectively communicate organizational ethics to their employees [82]. They must see ethics as an essential part of a company's culture [84].

The two terms "sustainability" and "sustainable development" have been increasingly used in relation to organizational management [40]. Pursuing ethical business objectives serves sustainable development around the world, for example, sustaining a clean environment benefits everyone and promotes the sustainability of the planet [85]. The pursuit of ethical business objectives can be observed through corporate social responsibility (CSR) policy and performance. CSR is defined by the European Commission as "a concept whereby companies integrate social and environmental concerns in their business operations and in 
their interaction with their stakeholders on a voluntary basis" [28]. In the context of CSR, the concept of stakeholders is the central focus [86]. Companies should identify who the major stakeholders are. They must pay attention to the expectations of stakeholders [85]. Thus, it is necessary for companies to identify the expectations of different stakeholders $[86,87]$. But they probably cannot respond to the wide variety of expectations immediately. Whereas stakeholders show many expectations, companies can only pursue several objectives at the same time [86]. Therefore, companies require the capability to identify and prioritize the corporate sustainability practices that are most important in enhancing corporate sustainable development [88].

In this paper, the establishment of organizational ethics is considered as a proper method for achieving sustainable development goals. This assumption is consistent with several studies (e.g. Fray [89], Payne and Raiborn [9o]) which highlighted the link between ethics and sustainable development, for example, the focus on the impact of ethics on behavior in terms of social responsibility and sustainable development [89]. Since organizations may have questions about how to create organizational ethics, previous studies maintain that the development of an ethical culture together with the ethical climate, produces organizational ethics [53]. Ethical climate and culture in the organization encourage its members to act correctly in accordance with the understanding of ethics. A study of a CSR-based model of clinical governance by Tuan and Ngoc [91] asserts that ethics guides the organizations' members to focus on the long-term strategy toward sustainable development of the community and sustainable growth of the organizations. However, a challenge for companies in changing environments (such as economic and political changes) is how to remain ethical in line with the concept of sustainable development.

A study by Payne and Raiborn [9o] identified four levels of sustainable development efforts for businesses. The level of sustainable development efforts reflects the degree to which sustainable development performance of a company is derived from a philosophy of ethics [90]. A business can determine its participation in sustainable development activities by using the hierarchy of ethical behavior as a tool [9o]. The first level is the basic level of behavior; companies perform to a legally acceptable level. They are more likely to comply with the letter of the law than the spirit of the law. They view sustainable development programs as providing a greater cost than benefit. Thus, they would make no effort to work for sustainable development. In the second level, currently attainable level of behavior; companies believe that some benefits arise from their practices in sustainable development programs. But they probably participate in sustainable development activities for the wrong reasons (e.g. cost reduction, revenue enhancement etc.) that provide them with short-term monetary benefits. In the third level, practical level of behavior; companies are concerned with doing the right thing relative to sustainable development. They choose to do it because it is right rather than because it provides short-term monetary benefits. They realize that the cost of pursuing sustainable development activities might be expensive but that they would receive greater long-term benefits. Fourth, theoretical level of behavior; companies participate and engage in sustainable development activities because these activities are ethical. This level reflects the highest spirit of morality.

The concept of the hierarchy of ethical behavior assists companies to differentiate each level of sustainable development efforts. They might decide whether it is the most beneficial way for them to climb up to the highest level of sustainable development efforts. If they create sustainable value which is consistent with ethical principles, they would gain not only economic benefits (i.e. monetary benefits), but also social benefits [92]. For instance, sometimes people's perception of businesses is not good because of their wrong behavior (corruption, tax avoidance etc.) [93]. Enhancing their business performance in relation to ethics makes their credibility increase [93]. Of course, their benefits can be both economic (profit, revenue) and social (to appear trustworthy to others). The presence of ethics in organizations is associated with sustainable success [94]. Normally, those companies that put a strong emphasis on organizational ethics often have clear direction with regards to achieving sustainable development goals. They have a clearer point of view whereby ethics is involved in every aspect of business performance [9o].

According to the hierarchy of ethical behaviour [9o], it can be concluded that the achievement of sustainable development depends on the degree to which a company holds an ethical philosophy. A deep understanding of ethics and a capability to interpret the philosophy of ethics into practical applications are necessary to improve the quality of a company's ethical performance [95]. Similarly, this paper considers organizational ethics as an important determinant of sustainable development. Building a strong sense of ethics in organizations help them to remain ethical in contemporary business environments and to attain sustainable development goals [96]. Companies with the spirit of ethics put more efforts to serve sustainable development than those who just follow the letter of the law. Their ethical performance not only results in higher business growth, but also produces benefits for other people (e.g. save the planet). The ultimate goal of business growth is sustainable growth [97]. One of the mainstreams of sustainable growth is ethics [97]. Businesses that aim to achieve sustainable growth should focus on enhancing their ethical climate and ethical culture, since these factors provide support to accomplish sustainable growth [97]. 


\section{Conclusion}

Whereas research on the role of organizational ethics in sustainable development was rarely seen in the past, it needs to be explored further in order to gain insight into the relationship between organizational ethics and sustainable development. Future research on organizational ethics should focus on ethical climate and culture in various types of organizations and in different countries. This is because people from different cultures might have different perceptions of ethics and sustainable development.

Besides organizational ethics (i.e. ethics at organizational level), ethics at the individual level can have an impact on sustainable development as well. It is reasonable to comment that research on ethics at the individual level should be investigated in order to obtain sufficient knowledge on this issue [98]. Research findings of ethics at the individual level (e.g. Elango, Paul, Kundu and Paudel [99], Guler and Yukselen [10o]) could be applied to strengthen ethical performance of an organization. The accomplishment of ethical performance requires individuals who are concerned about the rights and well-being of others [93].

\section{Acknowledgements}

We would like to thank our universities, Prince of Songkla University (PSU) and Universiti Utara Malaysia (UUM) for giving us the great opportunity to develop this paper. We also would like to give a special thanks to the staff of our universities who were very helpful. We appreciate all of the support of UUM Library (Perpustakaan Sultanah Bahiyah at Sintok Campus) and PSU Library (John F. Kennedy Library at Pattani Campus).

\section{References}

[1] Altıntaş MH, Kıliç S, Senol G, Isin FB. Strategic objectives and competitive advantages of private label products: Manufacturers' perspective. International Journal of Retail $\mathcal{E}$ Distribution Management 2010;38(10):773-788.

[2] Liu CH, Wang CC. Formulating service business strategies with integrative services model from customer and provider perspectives. European Journal of Marketing 2010;44(9/10):15001527.

[3] Phongpetra V, Johri LM. Impact of business strategies of automobile manufacturers in Thailand. International Journal of Emerging Markets 2011;6(1):17-37.

[4] Koch C. An ethical justification of profit maximization. Society and Business Review 2010;5(3):270-280.

[5] Kuethe TH, Morehart M. The profit impacts of risk management tool adoption. Agricultural Finance Review 2012;72(1):104-116.

[6] Paulet E. Banking ethics. Corporate Governance 2011;11(3):293300.

[7] Fafatas SA. Auditor conservatism following audit failures. Managerial Auditing Journal 2010;25(7):639-658.
[8] Eldridge S, Van Iwaarden J, Van Der Wiele T, Williams R. Management control systems for business processes in uncertain environments. International Journal of Quality $\mathcal{E}$ Reliability Management 2014;31(1):66-81.

[9] Joseph C. Understanding sustainable development concept in Malaysia. Social Responsibility Journal 2013;9(3):441-453.

[10] Winnard J, Adcroft A, Lee J, Skipp D. Surviving or flourishing? Integrating business resilience and sustainability. Journal of Strategy and Management 2014;7(3):303-315.

[11] United Nations. Report of the World Commission on Environment and Development: Our common future, 1987, http://daccess-dds-

ny.un.org/doc/UNDOC/GEN/N87/184/67/IMG/N8718467.pdf? OpenElement. Accessed 25 June 2015.

[12] Bredillet C. Ethics in project management: Some Aristotelian insights. International Journal of Managing Projects in Business 2014;7(4):548-565.

[13] Kooskora M. Corporate governance from the stakeholder perspective, in the context of Estonian business organizations. Baltic Journal of Management 2008;3(2):193-217.

[14] Davis G, Searcy C. A review of Canadian corporate sustainable development reports. Journal of Global Responsibility 2010;1(2):316-329.

[15] Wallis SE. Developing effective ethics for effective behavior. Social Responsibility Journal 2010;6(4):536-550.

[16] Grbac B, Lončarić D. Ethics, social responsibility and business performance in a transition economy. EuroMed Journal of Business 2009;4(2):143-158.

[17] Moyeen A, West B. Promoting CSR to foster sustainable development: Attitudes and perceptions of managers in a developing country. Asia-Pacific Journal of Business Administration 2014;6(2):97-115.

[18] Liu Z, Li J, Zhu H, Cai Z, Wang L. Chinese firms' sustainable development - The role of future orientation, environmental commitment, and employee training. Asia Pacific Journal of Management 2014;31(1):195-213.

[19] Banerjea PK. Wholesome ethical leadership. The IUP Journal of Corporate Governance 2010;9(1/2):7-14.

[20]Shafer WE, Poon MCC, Tjosvold D. An investigation of ethical climate in a Singaporean accounting firm. Accounting, Auditing $\mathcal{E}$ Accountability Journal 2013;26(2):312-343.

[21] Shapira-Lishchinsky O. Teachers' withdrawal behaviors: Integrating theory and findings. Journal of Educational Administration 2012;50(3):307-326.

[22] Chong M. Employee participation in CSR and corporate identity: Insights from a disaster-response program in the AsiaPacific. Corporate Reputation Review 2009;12(2):106-119.

[23] Moon HK, Choi BK. How an organization's ethical climate contributes to customer satisfaction and financial performance: Perceived organizational innovation perspective. European Journal of Innovation Management 2014;17(1):85-106.

[24] Wong SC, Li JS. Will hotel employees' perception of unethical managerial behavior affect their job satisfaction? A study of Chinese hotel employees in China. International Journal of Contemporary Hospitality Management 2015;27(5):853-877.

[25] Valentine S, Hollingworth D, Eidsness B. Ethics-related selection and reduced ethical conflict as drivers of positive work attitudes: Delivering on employees' expectations for an ethical workplace. Personnel Review 2014;43(5):692-716.

[26] Schwepker Jr CH, Schultz RJ. The impact of trust in manager on unethical intention and customer-oriented selling. Journal of Business \& Industrial Marketing 2013;28(4):347-356. 
[27] Hahn R. Integrating corporate responsibility and sustainable development: A normative-conceptual approach to holistic management thinking. Journal of Global Responsibility 2011;2(1):8-22.

[28] Shapira-Lishchinsky O, Rosenblatt Z. Perceptions of organizational ethics as predictors of work absence: A test of alternative absence measures. Journal of Business Ethics 2009;88(4):717-734.

[29] Choe SY, Min KH. Who makes utilitarian judgments? The influences of emotions on utilitarian judgments. Judgment and Decision Making 2011;6(7):580-592.

[30] Nafukho FM. Capacity building through investment in people: Key to Africa's development. European Journal of Training and Development 2013;37(7):604-614.

[31] Trainer T. Development, charity and poverty: The appropriate development perspective. International Journal of Social Economics 2002;29(1/2):54-72.

[32] Ciegis R, Kliucininkas L, Ramanauskiene J. Assessment of state and tendencies of sustainable development in Lithuania. Management of Environmental Quality: An International Journal 2011;22(6):757-768.

[33] Asif M, Searcy C. Towards a standardised management system for corporate sustainable development. The TQM Journal 2014;26(5):411-430.

[34] Global Cities Research Institute. Annual Review Global Cities, 2012, http://global-cities.info/wp-content/uploads/2013/o6/GCRI-2012Annual-Review-REV-Web-Version.pdf

[35] Wu Q, He Q, Duan Y. Explicating dynamic capabilities for corporate sustainability. EuroMed Journal of Business 2013;8(3):255-272.

[36] Chow WS, Chen Y. Corporate sustainable development: Testing a new scale based on the Mainland Chinese context. Journal of Business Ethics 2012;105(4):519-533.

[37] Bai C, Sarkis J, Dou Y. Corporate sustainability development in China: Review and analysis. Industrial Management $\mathcal{E}$ Data Systems 2015;115(1):5-40.

[38] Swanson LA, Zhang DD. Perspectives on corporate responsibility and sustainable development. Management of Environmental Quality: An International Journal 2012;23(6):630639.

[39] Lin CY, Ho YH. Determinants of green practice adoption for logistics companies in China. Journal of Business Ethics 2011;98:67-83.

[40]Ratiu C, Anderson BB. The identity crisis of sustainable development. World Journal of Science, Technology and Sustainable Development 2014;11(1):4-15.

[41] Lombardi MFS, Leal CC, Basso LFC. The activity of Natura from the perspective of sustainable development and of corporate social responsibility. Management Research: The Journal of the Iberoamerican Academy of Management 2010;8(3):165-182.

[42] Wang CJ. Do ethical and sustainable practices matter? Effects of corporate citizenship on business performance in the hospitality industry. International Journal of Contemporary Hospitality Management 2014;26(6):930-947.

[43] Carreira FA, Guedes MDA, Aleixo MDC. Can we teach ethics and professional deontology? An empirical study regarding the Accounting and Finance degree. Social Responsibility Journal 2008;4(1/2):89-103.

[44]Smith GE, Barnes KJ, Harris C. A learning approach to the ethical organization. The Learning Organization 2014;21(2):113125 .
[45] Brooks LJ, Dunn P. Business \& professional ethics for directors, executives $\mathcal{E}$ accountants6th ed. Canada: South-Western, Cengage Learning; 2012.

[46] McDonald F, Simpson C, O’Brien F. Including organizational ethics in policy review processes in healthcare institutions: A view from Canada. HEC Forum 2008;20(2):137-153.

[47]Connor KT. Assessing organizational ethics: Measuring the gaps. Industrial and Commercial Training 2006;38(3):148-155.

[48]Beeri I, Dayan R, Vigoda-Gadot E, Werner SB. Advancing ethics in public organizations: The impact of an ethics program on employees' perceptions and behaviours in a regional council. Journal of Business Ethics 2013;112(1):59-78.

[49]Steinmann H. Towards a conceptual framework for corporate ethics: Problems of justification and implementation. Society and Business Review 2008;3(2):133-148.

[50]De Schrijver A, Maesschalck J. The development of moral reasoning skills in police recruits. Policing: An International Journal of Police Strategies E Management 2015;38(1):102-116.

[51] McNutt PA, Batho CA. Code of ethics and employee governance. International Journal of Social Economics 2005;32(8):656-666.

[52] Tuan LT. Corporate social responsibility, ethics, and corporate governance. Social Responsibility Journal 2012;8(4):547-560.

[53] Sekerka LE, Comer DR, Godwin LN. Positive organizational ethics: Cultivating and sustaining moral performance. Journal of Business Ethics 2014;119(4):435-444.

[54] Koh HC, Boo EHY. Organisational ethics and employee satisfaction and commitment. Management Decision 2004;42(5):677-693.

[55] Tuan LT. Corporate social responsibility, ethics, and corporate governance. Social Responsibility Journal 2012;8(4):547-560.

[56]Creswell JW. Research design: Qualitative $\mathcal{E}$ quantitative approaches. Thousand Oaks: SAGE Publications; 1994.

[57] Powell SM. The nexus between ethical corporate marketing, ethical corporate identity and corporate social responsibility: An internal organisational perspective. European Journal of Marketing 2011;45(9/10):1365-1379.

[58] Tsai MT, Huang CC. The relationship among ethical climate types, facets of job satisfaction, and the three components of organizational commitment: A study of nurses in Taiwan. Journal of Business Ethics 2008;80(3):565-581.

[59]Laratta R. Ethical climate in nonprofit organizations: A comparative study. International Journal of Sociology and Social Policy 2009;29(7/8):358-371.

[6o]Choi BK, Moon HK, Ko W. An organization's ethical climate, innovation, and performance: Effects of support for innovation and performance evaluation. Management Decision 2013;51(6):1250-1275.

[61] Shin Y. CEO ethical leadership, ethical climate, climate strength, and collective organizational citicenship behavior. Journal of Business Ethics 2012;108(3):299-312.

[62] Shapira-Lishchinsky O, Rosenblatt Z. School ethical climate and teachers' voluntary absence. Journal of Educational Administration 2010;48(2):164-181.

[63] Shafer WE. Ethical climate, social responsibility, and earning management. Journal of Business Ethics 2015;126(1):43-6o.

[64] Kim NY, Miller G. Perceptions of the ethical climate in the Korean tourism industry. Journal of Business Ethics 2008;82(4):941-954.

[65] Martin KD, Cullen JB. Continuities and extensions of ethical climate theory: A meta-analytic review. Journal of Business Ethics 2006;69(2):175-194. 
[66]Ling L, Qing T, Shen P. Can training promote employee organizational commitment? The effect of employability and expectation value. Nankai Business Review International 2014;5(2):162-186.

[67] Enache M, Sallán JM, Simo P, Fernandez V. Organizational commitment within a contemporary career context. International Journal of Manpower 2013;34(8):88o-898.

[68]Huhtala M, Kangas M, Lämsä AM, Feldt T. Ethical managers in ethical organizations? The leadership-culture connection among Finnish managers. Leadership $\mathcal{E}$ Organization Development Journal 2013;34(3):250-270.

[69]Svanberg J, Öhman P. Auditors' time pressure: Does ethical culture support audit quality? Managerial Auditing Journal 2013;28(7):572-591.

[70] Riivari E, Lämsä AM, Kujula J, Heiskanen E. The ethical culture of organisations and organisational innovativeness. European Journal of Innovation Management 2012;15(3):310-331.

[71] Small MW. Management development: Developing ethical corporate culture in three organisations. Journal of Mangement Development 2006;25(6):588-6oo.

[72] Mysen T. Sustainability as corporate mission and strategy. European Business Review 2012;24(6):496-509.

[73] Pflugrath G, Martinov-Bennie N, Chen L. The impact of codes of ethics and experience on auditor judgments. Managerial Auditing Journal 2007;22(6):566-589.

[74] Whyatt G, Wood G, Callaghan M. Commitment to business ethics in UK organizations. European Business Review 2012;24(4):331-350.

[75] Park H, Blenkinsopp J. The impact of ethics programmes and ethical culture on misconduct in public service organizations. International Journal of Public Sector Management 2013;26(7):520-533.

[76] Irwin J, Bradshaw K. The ethics challenge: Establishing an ethics ambassador network to help embed an ethical culture. Strategic HR Review 2011;10(4):26-32.

[77] Kaptein M. Developing and testing a measure for the ethical culture of organizations: The corporate ethical virtues model. Journal of Organizational Behavior 2008;29(7):923-947.

[78] Ciasullo MV, Troisi O. Sustainable value creation in SMEs: A case study. The TQM Journal 2013;25(1):44-61.

[79] Milne MJ, Tregidga H, Walton S. Words not action! The ideological role of sustainable development reporting. Accounting, Auditing \& Accounting Journal 2009;22(8):1211-1257.

[8o]Venkatraman S, Nayak RR. Relationships among triple bottom line elements: Focus on integrating sustainable business practices. Journal of Global Responsibility 2015;6(2):195-214.

[81] Musgrave J. Moving towards responsible events management. Worldwide Hospitality and Tourism Themes2011;3(3):258-274.

[82] Magill G, Prybil L. Stewardship and integrity in health care: A role for organizational ethics. Journal of Business Ethics 2004;50(3):225-238.

[83] Morris L, Wood G. A model of organizational ethics education. European Business Review 2011;23(3):274-286.

[84] Kevany KD. Building the requisite capacity for stewardship and sustainable development. International Journal of Sustainability in Higher Education 2007;8(2):107-122.

[85] Depoo T, Rosner DJ. The ethical dilemma of sustainable development: Guyana. Journal of Global Responsibility 2011;2(1):75-84.

[86]Bouglet J, Joffre O, Simon E. How to reconcile business with sustainable development: An innovation approach. Society and Business Review 2012;7(3):212-222.
[87] Kurniawan F, Ogunlana S, Motawa I. Stakeholders' expectations in utilising financial models for public-private partnership projects. Built Environment Project and Asset Management 2014;4(1):4-21.

[88] Goyal P, Rahman Z, Kazmi AA. Identification and prioritization of corporate sustainability practices using analytical hierarchy process. Journal of Modelling in Management 2015;10(1):23-49.

[89]Fray AM. Ethical behavior and social responsibility in organizations: Process and evaluation. Management Decision 2007;45(1):76-88.

[9o]Payne DM, Raiborn CA. Sustainability development: The ethics support the economics. Journal of Business Ethics 2001;32(2):157-168.

[91] Tuan LT, Ngoc LTB. CSR-based model of clinical governance. International Journal of Pharmaceutical and Healthcare Markrting 2014;8(1):62-97.

[92] Aras G, Crowther D. Governance and sustainability: An investigation into the relationship between corporate governance and corporate sustainability. Management Decision 2008;46(3):433-448.

[93] Rogojanu A, Badea L. Business ethics and education - An intelligent solution or a sustainable development? Equilibrium 2011;6(4):21-37.

[94]Lin-Hi N, Blumberg I. The relationship between corporate governance, global governance, and sustainable profits: Lessons learned from BP. Corporate Governance 2011;11(5):571-584.

[95] Shengtian H, Weihui F, Xiaosong L. Achieving sustainability with a stakeholder-based CSR assessment model for FIEs in China. Journal of International Business Ethics 2010;3(1):41-55.

[96]Brady K. Freelance technical writers: Does temporary work promote ethical issues? Journal of Information, Communication $\mathcal{E}$ Ethics in Society 2011;9(1):34-48.

[97] Nguyen LD, Mujtaba BG, Tran CN, Tran QHM. Sustainable growth and ethics: A study of business ethics in Vietnam between business students and working adults. The South East Asian Journal of Management 2013;7(1):41-56.

[98]Appelbaum SH, Vigneault L, Walker E, Shapiro BT. (Good) corporate governance and the strategic integration of meso ethics. Social Responsibility Journal 2009;5(4):525-539.

[99]Elango B, Paul K, Kundu SK, Paudel SK. Organizational ethics, individual ethics, and ethical intentions in international decision-making. Journal of Business Ethics 2010;97(4):543-561.

[10o] Guler EG, Yukselen C. Hotel employees' beliefs on unethical behavior. Social Responsibility Journal 2010;6(2):252-267. 